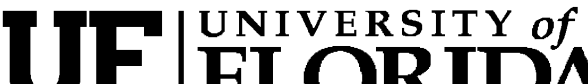 FLORIDA \\ IFAS Extension
}

\section{Wetland Delineation: An Overview of Regulations and Methods 1}

Daniel L. Irick, Yuncong Li, and Alan L. Wright ${ }^{2}$

The purpose of this document is to describe the regulatory nature of wetland delineation and classification. This document should be of interest to landowners, wetland and soil scientists, and the general public.

\section{Regulatory Framework}

\section{Federal}

Wetland areas are defined with respect to the federal regulatory policy within Title 33 of the Code of Federal Regulations Part 328 (33 CFR 328) as "those areas that are inundated or saturated by surface or ground water at a frequency and duration sufficient to support, and that under normal circumstances do support, a prevalence of vegetation typically adapted for life in saturated soil conditions. Wetlands generally include swamps, marshes, bogs, and similar areas."

Federal regulations outlined in the Rivers and Harbors Act of 1899 (U.S.C. 403) (http://www.wetlands.com/regs/rhasc403.htm) and the Clean Water Act (CWA) (U.S.C. 1251-1387) (http://www.wetlands.com/regs/tlpge02c.htm) govern land-use activities within "waters of the United States". The United States (U.S.) Environmental Protection Agency (EPA) and the U.S. Army Corps of Engineers (Corps) have federal regulatory authority over water bodies deemed jurisdictional. Waters of the U.S. and the extent of federal jurisdiction are defined within (33 CFR 328); "waters of the United States" specifically encompasses wetland areas. However, although some wetlands are included in this definition, not all wetlands within the landscape of the U.S. are "waters of the United States" and therefore are not subject to federal regulations.

The Corps is the primary regulatory authority with respect to the determination of the presence of jurisdictional wetlands on non-agricultural lands of the U.S. and the extent of federal jurisdiction, which is determined by conducting a delineation of wetland boundaries. In addition, Section 404 of the CWA (33 U.S.C. 1344) extends authority to the Corps to issue federal permits for activities involving discharge of dredged or fill material into "navigable waters of the United States". Waters defined as navigable include "waters of the United States including territorial

1. This document is SL 289, one of a series of the Soil and Water Science Department, Florida Cooperative Extension Service, Institute of Food and Agricultural Sciences, University of Florida. Original publication date May 2009. Visit the EDIS Web Site at http://edis.ifas.ufl.edu.

2. Daniel L. Irick, graduate student, Department of Soil and Water Science; Yuncong Li, professor, Department of Soil and Water Science, Tropical Research and Education Center (REC)--Homestead; Alan L. Wright, assistant professor, Department of Soil and Water Science, Everglades REC--Belle Glade; Florida Cooperative Extension Service, Institute of Food and Agricultural Sciences, University of Florida, Gainesville, FL 32611.

The Institute of Food and Agricultural Sciences (IFAS) is an Equal Opportunity Institution authorized to provide research, educational information and other services only to individuals and institutions that function with non-discrimination with respect to race, creed, color, religion, age, disability, sex, sexual orientation, marital status, national origin, political opinions or affiliations. U.S. Department of Agriculture, Cooperative Extension Service, University of Florida, IFAS, Florida A. \& M. University Cooperative Extension Program, and Boards of County Commissioners Cooperating. Millie Ferrer, Interim Dean. 
seas," per Section 502(7) of the CWA. Proposed land-use activities that will involve discharge of dredged or fill material within jurisdictional wetlands are subject to Corps review and approval through the Section 404 permitting process.

The United States Department of Agriculture Natural Resource Conservation Service (USDA-NRCS) determines the presence or absence of wetlands on land under agricultural production for the purpose of implementing provisions of The Food Security Act of 1985 (Swampbuster Act). Provisions of the Swampbuster Act are outlined in Title 7 CFR Part 12. The Swampbuster Act provisions prohibit landowners, or lessees, from participating in USDA-NRCS benefit programs if agricultural activities conducted after December 23, 1985 result in conversion of wetlands to commodity crop production without providing mitigation for impacts to wetland function and loss of acreage. Current policy implemented by both the EPA and the Corps, and the USDA-NRCS, dictates land use activities on both agricultural and non-agricultural lands do not result in a loss of wetland acreage or function.

\section{State, County, and Municipality}

Regulation of land-use activities within wetlands may also occur at the state, county and local municipality level. The State of Florida administrative code defines wetland areas under state jurisdiction within Section 19 of Title 28 of The Florida Statutes, Chapter 373. The Department of Environmental Protection and the Water Management Districts (Florida is divided into five Districts) are the primary agencies with regulatory authority over wetlands in Florida. Review of the state administrative code as well as county and local municipality codes and ordinances should occur prior to initiation of any activities within or adjacent to landscape features that may potentially be wetlands.

Wetland regulations administered at the state, county, and local municipality level typically expand upon the scope of federal regulations. The ecological importance of wetland areas, independent of federal jurisdictional status, is well documented for protection of water quality and wildlife habitat. If regulations are in place at the state, county or local municipality level, they are generally written to be inclusive of wetlands that are not subject to federal regulations. An example is hydrologically-isolated wetlands, which includes wetlands not adjacent to "waters of the United States."

The purpose of most wetland regulations implemented beyond those established by federal agencies is not only to limit activities within delineated wetland boundaries, but also to extend land-use restrictions onto adjacent uplands. Often these restrictions include development and building setbacks and protection or creation of vegetated uplands. These uplands are usually referred to within regulatory language as protective buffers.

\section{Wetland Delineation}

Determination of the boundary between wetlands and adjacent uplands is termed wetland delineation. Specific methods, identified by federal or state agencies or municipalities, are employed to determine wetland boundaries within landscapes. These methods are not intended to define individual wetlands from a scientific perspective, but rather are used to verify the extent of areas regulated by policy. A delineated wetland boundary should be established and agreed upon by the agency with regulatory authority during the initial planning stages of proposed land-use projects in order for landowners to maintain regulatory compliance. However, it should be noted that some activities, including agriculture, may be exempt from regulatory restrictions and permitting requirements. The primary purpose of delineating wetland boundaries is to determine the presence and extent of wetland areas subject to regulatory policy. Therefore, delineation of existing wetlands may not be necessary if a proposed land-use activity is exempted by a policy established by the agency with regulatory authority.

The following sections provide an overview of guidelines established by the Corps for delineating wetlands on non-agricultural lands of the U.S. which are subject to federal regulations under the CWA. The Florida Wetlands Delineation Manual should be reviewed prior to delineating wetlands that may be solely regulated under state authority. Land under agricultural production is subject to provisions of the Swampbuster Act and wetland determinations are 
conducted and certified by the USDA-NRCS.

Landowners and potential lessees should contact their regional USDA-NRCS office for questions regarding USDA-NRCS certified wetland determinations on land they own, plan to purchase or lease.

\section{Corps of Engineers Wetland Delineation Manual}

In 1987, the Corps published a wetland delineation manual (1987 Manual) in an effort to provide methodology for wetland delineations pertaining to federal regulations. The methods emphasize that wetland determinations are based on the identification of specific hydrologic requirements, presence of hydric soils, and a dominance of vegetative species suited to continued or periodic inundated or saturated soil conditions. Except for situations specifically detailed in the manual, each of these parameters must be observed to confirm the presence of wetland conditions. If a wetland is determined to be present, the boundary between wetland and upland exists where one of the three parameters is no longer evident. The techniques described in the manual are used by the Corps to determine the presence and extent of wetlands that are classified as jurisdictional waters of the U.S.

\section{Regional Supplements}

Wetland types vary throughout the diverse geographic and climatic regions of the U.S. Their dynamic nature and characteristic variability throughout the U.S. can pose difficulties in determination of delineated boundaries using comprehensive federal methods. In 2002 the Corps published a technical report addressing the importance of developing regional revisions to the 1987 Manual.

Development and implementation of regional supplements to the 1987 Manual have since been initiated by the Corps. Ten regions have been identified for which supplemental procedural guidance to the 1987 Manual (Figure 1), specific to respective regions, will be implemented. The regions identified include Alaska, Arid West, Atlantic and Gulf Coastal Plain, Caribbean Islands, Eastern Mountains \& Piedmont, Great Plains, Hawaii and Pacific Islands, Midwest, Northcentral and Northeast, and Western Mountains, Valleys \& Coast (Western Mountains).

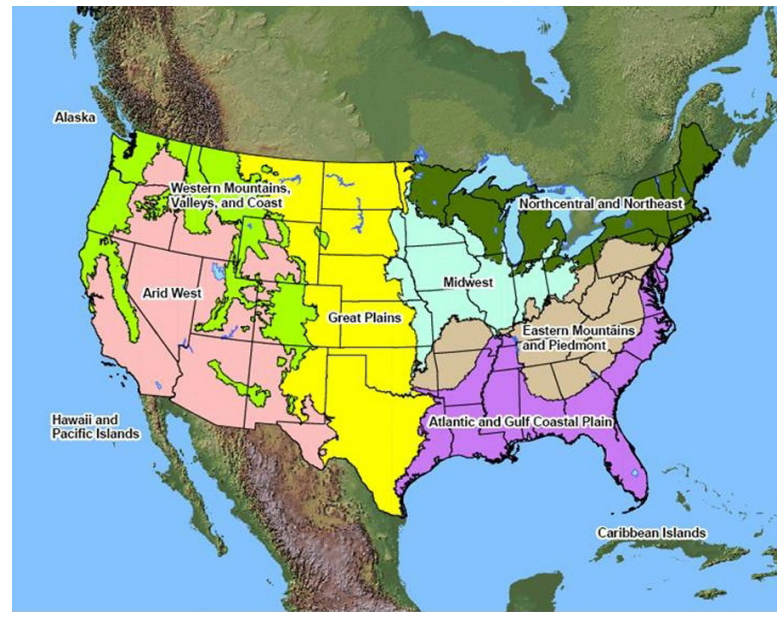

Figure 1. The U.S. Army Corps of Engineers map of regions across the United States.

Each regional supplement is intended for use in conjunction with the 1987 Manual and their primary purpose is to address "regional differences in climate, geology, soils, hydrology, plant and animal communities, and other factors important to the identification and functioning of wetlands." The Corps recognizes that scientific advances in the disciplines associated with wetland science and ecology have continued since the publication of the 1987 Manual. Many of the methods and procedural guidelines in the 1987 Manual are still valid, however, some notable changes reflecting more recent scientific advances are outlined in the regional supplements.

Florida is within the Atlantic and Gulf Coastal Plain region and the Corps published the interim supplement in October 2008. Application of the supplemental guidance is required for delineation of federally regulated wetlands within this region. Information regarding the development status of each regional supplement and downloadable versions of supplemental documentation can be accessed through the Corps Civil Works Regulatory Program web site

( http://www.usace.army.mil/CECW/Pages/ cecwo_reg.aspx).

Within the introductory chapter of each supplement is a table that describes all sections of the 
1987 Manual that should be replaced by sections of their respective regional supplemental. This table is consistent throughout all of the finalized and interim supplemental documents published to date and details regarding the regional differences in methodology and procedure are addressed. These sections of each supplement describe updated, regional specific methods for determination of vegetation communities dominated by hydrophytes, presence of hydric soils, and presence of hydrologic indicators indicative of wetland conditions. In addition, a revised definition of "growing season" is detailed, as well as guidance for hydrological determinations for problematic, or highly disturbed, wetlands.

\section{References}

Braddock, T. and L. Berntsen. 2007. "Wetlands: An Introduction to Ecology, the Law, and Permitting, Second Edition," Government Institutes, Lanham, MD.

Environmental Laboratory. 1987. "Corps of Engineers Wetland Delineation Manual," Technical Report Y-87-1, U.S. Army Engineers Waterways Experiment Station, Vicksburg, MS.

Heimlich, R.E., K.D. Wiebe, R. Claassen, D. Gadsby, and R.M. House. 1998. "Wetlands and Agriculture: Private Interests and Public Benefits," Resource Economics Division, Economic Research Service, U.S. Department of Agriculture. Agricultural Economic Report No. 765.

Mitsch, W.J. and J.G. Gosselink. 2000. "Wetlands, Third Edition,” John Wiley \& Sons, Inc., New York, NY.

U.S. Army Corps of Engineers. 2008. U.S. Army Engineer Research and Development Center. "Interim Regional Supplement to the Corps of Engineers Wetland Delineation Manual: Atlantic and Gulf Coastal Plain Region, ed. J.S. Wakeley, R.W. Lichvar, and C.V. Noble. ERDC/EL TR-08-30. Vicksburg, MS.

U.S. Army Corps of Engineers. 2007. U.S. Army Engineer Research and Development Center. "Regional Supplement to the Corps of Engineers Wetland Delineation Manual: Alaska Region
(Version 2.0), ed. J.S. Wakeley, R.W. Lichvar, and C.V. Noble. ERDC/EL TR-07-24. Vicksburg, MS.

Wakeley, J.S. 2002. "Developing a Regionalized Version of the Corps of Engineers Wetlands Delineation Manual: Issues and Recommendations," ERDC/EL TR-02-20, U.S. Army Engineer Research and Development Center, Vicksburg, MS. 